Dr DALIBOR VELOJIĆ, naučni saradnik

Institut za srpsku kulturu

Priština - Leposavić, Republika Srbija

d.velojic@yahoo.com

UDK: 37.014.22:355.233(497.1)"1918/1941"

originalan naučni rad

primljeno: 31. oktobar 2017.

prihvaćeno: 10. oktobar 2018.

https://doi.org/10.29362/ist20veka.2019.1.vel.37-52

\title{
ANALFABETSKI KURSEVI U VOJSCI KRALJEVINE SHS/JUGOSLAVIJE 1918-1941.*
}

APSTRAKT: U radu se obrađuje opismenjavanje vojnika putem organizovanja analfabetskih kurseva u periodu 1918-1941. Kao institucija čije je funkcionisanje zahtevalo stručne kadrove, vojska je na elementarnom opismenjavanju regruta radila zajedno sa ministarstvom prosvete angažovanjem mesnih učitelja. Ako se u obzir uzmu redovne vojne aktivnosti, primetno je da broj kurseva održanih u vojsci nije zaostajao za civilnim, kao ni kvalitet pokazan na predavanjima. Korišćena je građa prvenstveno pohranjena u Arhivu Jugoslavije, kao i objavljeni statistički podaci za međuratni period.

KLJUČNE REČI: pismenost, Vojska Kraljevine SHS/Jugoslavije, opismenjavanje regruta, analfabetski kursevi

\section{Prosvetne prilike u zemlji}

Pismenost stanovništva u Kraljevini SHS/Jugoslaviji pratila je opšte stanje u društvu, kao i različitosti sa kojima se susrela novostvorena država. ${ }^{1}$ Različito zakonodavstvo određivalo je i različite sisteme školovanja, ${ }^{2}$ ali je i kulturni nivo takođe uticao na svest stanovnika o neophodnosti obrazovanja. Na teritoriji

\footnotetext{
* Rad je deo projekta Materijalna i duhovna kultura Kosova i Metohije (178028), koji finansira Ministarstvo prosvete, nauke i tehnološkog razvoja Republike Srbije.

${ }^{1}$ Opširnije videti: Љубодраг Димић, Културна политика Краљевине Југославије, I-II (Београд: Стубови културе, 1996-1997); Мари Жанин Чалић, Социјална историја Србије 1815-1941 (Београд: Clio, 2004); Момчило Исић, Основно школство у Србији 1918-1941, I-II (Београд: Інститут за новију историју Србије, 2005); Исти, „Неуспех основношколског система у Србији за време Краљевине Југославије“, Токови историје, бр. 4, (2006), 31-55; Владан Јовановић, Вардарска бановина 1929-1941 (Београд: Институт за новију историју Србије, 2011).

${ }^{2}$ Momčilo Isić je u svom istraživanju naveo razlike u trajanju osnovne škole, pri čemu su, prema četiri razreda u Srbiji, Crnoj Gori i Bosni i Hercegovini, deca u Hrvatskoj i Sloveniji išla u osnovnu školu pet godina. U Dalmaciji je osnovna škola trajala šest, a u Mariborskoj oblasti osam razreda. М. Исић, „Неуспех основношколског система у Србији“, 31-32. Izjednačavanje školskog sistema u Hrvatskoj regulisano je u Nacrtu ustava Neutralne seljačke republike Hrvatske iz 1921. po kome bi osnovne škole trajale četiri godine. Dušan Bajagić, „Stjepan Radić kao ministar prosvete Kraljevine Srba, Hrvata i Slovenaca“, Tokovi istorije, br. 4, (2006), 141.
} 
Slovenije i Hrvatske, gde su važili zakoni iz perioda Austro-Ugarske, procenat pismenog stanovništva bio je daleko veći nego u južnim krajevima. Dravska banovina je po popisu iz 1931. godine imala oko 94\% pismenih (skoro podjednako muškaraca i žena). ${ }^{3} \mathrm{U}$ obzir treba uzeti i činjenicu da je prosvetna organizacija u ovoj banovini bila mnogo naprednija i efikasnija nego u ostalim krajevima zemlje. Razvijena mreža školskih odbora, kao i ulaganja na lokalnom nivou, primeri su razvijene svesti o značaju obrazovanja. Za podizanje novih i opravku starih škola na lokalnom nivou izdvajane su prilične sume, koje su daleko nadmašile državna i banovinska sredstva. U procentima su sredstva države i banovine iznosila samo $10 \%$, dok su $90 \%$ obezbeđivale upravne opštine. ${ }^{4}$ Na teritoriji Hrvatske procenat pismenih muškaraca bio je znatno veći nego žena, naročito u primorju. Problemi oko izgradnje škola bili su finansijske prirode, ali potrebno je uzeti u obzir i robovanje administraciji nasleđeno iz vremena Austro-Ugarske. ${ }^{5}$ Po austrijskom sistemu u prethodnih četrdeset godina razvijalo se i školstvo na teritoriji Bosne i Hercegovine. Međutim, s obzirom na siromaštvo, brdovitost i kulturnu zaostalost, na ovim prostorima prosvetna politika nije u potpunosti zaživela. U izveštaju za Bosnu i Hercegovinu iz 1920. godine navedeno je da je AustroUgarska ostavila 320 osnovnih škola sa 900 učitelja, dakle jednu školu na 160 $\mathrm{km}^{2}$ i na 6.330 stanovnika, dok je jedan učitelj bio na 2.100 duša. Školu je pohađala petina dece, a nepismenih iznad sedam godina bilo je $87 \%{ }^{6}$

Teritorija Kraljevine Srbije oskudevala je u školskim zgradama, ali i u učiteljskom kadru, što se može opravdati sedmogodišnjim ratovanjem, okupacijom, velikim materijalnim razaranjima i ljudskim žrtvama. Pored toga, u zabačenim delovima Srbije nije ni postojala evidencija o broju dece stasale za školu, dok je, po patrijarhalnim shvatanjima, ženskoj deci obrazovanje bilo onemogućeno. Potrebno je uzeti u obzir i činjenicu da su neretko i deca zapošljavana u industriji, budući da je, u uslovima malih zarada i brojnog potomstva, njihov rad doprinosio poboljšanju porodičnih prihoda. U tom slučaju, često je zapostavljano školovanje na račun privređivanja i zarade. Takve pojave naročito su bile izražene u mestima sa malo ili bez škola, ili gde nije poštovana obaveza školovanja, s obzirom na velike troškove koje je ona iziskivala. ${ }^{7} \mathrm{Na}$ teritoriji Drinske banovine, gde je 1931. godine registrovano $37,9 \%$ pismenih, ${ }^{8}$ u proseku je jedna škola bila na 41 $\mathrm{km}^{2}$ i 2.351 stanovnika. ${ }^{9}$ U Dunavskoj banovini stanje je bilo zadovoljavajuće, kada se u obzir uzmu ulaganja u škole, naročito u periodu pre ekonomske krize.

\footnotetext{
${ }^{3}$ Definitivni rezultati popisa stanovništva od 31. marta 1931, knjiga III, prisutno stanovništvo po pismenosti i starosti (Beograd: Opšta državna statistika, 1938), 6.

${ }^{4}$ Prema podacima u periodu 1918-1937. godine upravne opštine su izdvojile preko 343.000.000 dinara, od kojih je trećina potrošena na izgradnju novih škola i opravku starih. Podignuto je 68 novih škola, a 93 su popravljene. Inače, najveća izdavanja bila su u periodu ekonomske krize. Љ. Димић, н. д., II, 9-10.

${ }^{5}$ Исто, $15-40$.

${ }^{6}$ Arhiv Jugoslavije (AJ), fond 66, Ministarstvo prosvete Kraljevine Jugoslavije, fascikla 2205, Izveštaj za Bosnu i Hercegovinu od 16. februara 1920.

${ }^{7}$ М. Ж. Чалић, н. д., 254.

${ }^{8}$ Definitivni rezultati popisa stanovništva od 31. marta 1931, III, 6.

${ }^{9}$ AJ, 66-2209, Izveštaj prosvetnog odeljenja Drinske banovine ministru prosvete broj 2086 od 8. 1. 1932.
} 
Daleko alarmantnije stanje bilo je na teritoriji Makedonije i Kosova i Metohije. Sa velikim procentom nepismenosti (preko $80 \%$, a u čisto albanskim i turskim krajevima i preko $90 \%)^{10}$ ove pokrajine su značajno zaostajale za ostatkom zemlje. Izrazita odbojnost prema školovanju bila je primetna kod albanskog stanovništva. Prema podacima, do 1929. godine petina izgrađenih škola bila je namenjena krajevima sa albanskom većinom, dok je samo 2\% Albanaca pohađalo te škole. ${ }^{11}$ Siromaštvo i neprosvećenost, plemenski običaji, ali i odsustvo želje da se inkorporiraju u novu zajednicu, dovodili su prosvetne vlasti u gotovo bezizlaznu situaciju. Pre svega, uslovi života bili su daleko ispod minimuma da bi se uopšte vodilo računa o školovanju dece. ${ }^{12}$ Nedovoljan broj škola, kao i velika udaljenost uticali su takođe na izostanak osnovnog obrazovanja. Patrijarhalna shvatanja, kao i verski obziri, koji smatraju da ženskoj deci pismenost nije neophodna, uticali su umnogome na daleko manji broj obrazovanih žena u odnosu na muškarce. Prema podacima, u čitavoj Jugoslaviji je $60 \%$ žena bilo nepismeno, dok je u Južnoj Srbiji taj broj iznosio $92 \%{ }^{13}$

Različito kulturno nasleđe $\mathrm{i}$ uslovi života doprineli su i različitom stepenu obrazovanja kod stanovništva. Nejednakosti i ekstremno nizak prag pismenosti u pojedinim oblastima, smanjivali su i ukupan procenat pismenosti. Prema podacima Ministarstva prosvete početkom 1926. na teritoriji čitave zemlje bilo je ukupno 48,5\% nepismenih. ${ }^{14}$ Slično je i sa podacima iz popisa stanovništva. Prema popisu iz 1921. godine bilo je 49,5\% pismenih starijih od 12 godina, dok je 1931. registrovano 55,4\% pismenih iznad 11 godina. Treba uzeti $\mathrm{u}$ obzir da se tokom deset godina pismenost povećala, naročito među mlađim generacijama, ali je i usled izumiranja starijih, nepismenijih, to povećanje iznosilo 5,9\%. Prema raspisu Ministarstva prosvete iz 1926. uzrok nepismenosti bio je, između ostalog, mali broj osnovnih škola. Osnovna nastava nije se razvijala $\mathrm{u}$ onoj razmeri kao nastava u srednjim i visokim školama, te je za njima bila $\mathrm{u}$ velikom zaostatku. Neophodno je bilo otvarati nove škole i proširivati ih tamo gde je bio veliki broj dece na jednog učitelja. Najsigurniji način za podizanje kulturnog i obrazovnog nivoa, prema Ministarstvu, bilo je valjano uređeno osnovno školstvo sa prikladnim školskim zgradama, naprednim nastavnim planovima, dobrim knjigama i stručnim nastavnim kadrom. ${ }^{15}$

Namera državnog vrha da svim raspoloživim sredstvima osnovno obrazovanje podigne na daleko viši nivo ogledala se, pre svega, u podizanju novih

\footnotetext{
${ }^{10}$ Владан Јовановић, „Историјско, свакодневно и приватно на простору Вардарске бановине“, у: Приватни живот код Срба у ХХ веку, уредник Милан Ристовић (Београд: Clio, 2007), 575.

${ }^{11}$ Исто. Vladan Jovanović beleži da je u 1932. godini jedna škola pokrivala $36 \mathrm{~km}^{2}$ ili 1.173 stanovnika. Исти, Вардарска бановина, 410.

12 O uslovima života, higijenskim i zdravstvenim prilikama i načinu ishrane videti: Војносанитетски статистички годишњак Краљевине СХС 1926. и 1927, књига II (Београд: Министарство војске и морнарице, 1928).

${ }^{13}$ В. Јовановић, „Историјско, свакодневно и приватно“, 575.

${ }^{14}$ AJ, 66-2215, Naredba ministra prosvete Kraljevine SHS br. 1325/III od 4. januara 1926.

${ }^{15}$ Isto.
} 
škola, kao i u školovanju stručnog kadra za potrebe nastave. Uzimajući u obzir manjak učitelja koji se osetio nakon završetka Prvog svetskog rata, naročito na teritoriji Srbije, preduzete su mere za popunu praznih mesta otvaranjem skraćenih kurseva, a otvorene su i nove učiteljske škole. ${ }^{16}$ Broj prosvetnih radnika je rastao iz godine u godinu, ali nedovoljno u odnosu na broj učenika. Tako je, primera radi, u Dravskoj banovini u školskoj 1934/1935. godini nedostajalo oko 400 učitelja, u Savskoj je na jednog učitelja dolazilo u pojedinim krajevima i do 200 učenika, a u Primorskoj i do $150 .{ }^{17}$ Vrbaska banovina je konstantno imala nedostatak od 10\% nastavnog kadra, dok su u Vardarskoj 1931. godine bila upražnjena 432 mesta. ${ }^{18}$ Drinskoj banovini je, prema izveštaju za 1931. godinu, nedostajalo 85 učitelja, prvenstveno muškaraca, pošto je najveća oskudica u zabačenim krajevima u kojima je opstanak učiteljici bio nemoguć. ${ }^{19}$

Što se osnovnih škola tiče, daleko veći problem bilo je izdvajanje sredstava za izgradnju novih i opravku starih zgrada. Izdvajanja za prosvetu u međuratnom periodu kretala su se u proseku 6-7\% budžeta, što je, s obzirom na alarmantno stanje u pojedinim krajevima, bilo nedovoljno. ${ }^{20}$ Imajući $\mathrm{u}$ vidu nesrazmeran razvoj dolazilo se i u situaciju da, primera radi, u pojedinim mestima Dravske banovine osnovni problem predstavlja uređenje školske biblioteke i nabavka nastavnih sredstava i pomagala, dok na jugu zemlje školske zgrade nisu pružale elementarne uslove za rad i smeštaj učenika.

U takvim uslovima jedan od načina opismenjavanja stanovništva bilo je organizovanje analfabetskih kurseva, na kojima je trebalo osposobiti što više odraslih osoba u čitanju, pisanju i osnovnim računskim radnjama.

\section{Analfabetski kursevi}

Sa obukom nepismenog stanovništva krenulo se odmah nakon završetka Prvog svetskog rata. Analfabetski kursevi otvarani su početkom 1920. godine po selima u Srbiji ${ }^{21}$ i bili su sastavni deo opšte strategije obrazovanja stanovništva. U objašnjenju Vrhovnog zakonodavnog saveta navodi se da narodne škole obuhvataju osnovne i više narodne škole, a da uz njih idu i zabavišta, škole za nedovoljno razvijene, analfabetski kursevi, kursevi za domaćice, higijenski kursevi, itd. ${ }^{22}$ Većeg maha kursevi uzimaju u Srbiji u 1921. godini, u Južnoj Srbiji i Bosni i Hercegovini tokom 1922, a od 1923. u Hrvatskoj, Slavoniji i Dalmaciji. ${ }^{23}$ Cilj

\footnotetext{
${ }^{16}$ Иван Бецић, „Рад на описмењавању регрута краљеве гарде 1933-1937“, Војно-историјски гласник, бр. 2, (2014), 203.

17 Љ. Димић, н. д., II, 12, 18, 38.

${ }^{18}$ Исто, 61, 109.

${ }^{19}$ AJ, 66-2209-7, Izveštaj Prosvetnog odeljenja Drinske banovine - ministru prosvete br. 2086 od 8. januara 1932.

${ }^{20}$ И. Бецић, н. д., 209. Vardarska banovina, primera radi, izdvajala je $5 \%$ iz budžeta za narodno prosvećivanje. В. Јовановић, Вардарска бановина, 410.

${ }^{21}$ AJ, 66-562, Naredba Ministarstva prosvete od februara 1920.

22 AJ, 66-116, Vrhovni zakonodavni savet Ministarstvu prosvete br. 270 od 11. septembra 1929.

${ }^{23}$ AJ, fond 38, Centralni presbiro Predsedništva Ministarskog saveta Kraljevine Jugoslavije, 64169, Razvoj analfabetskih kurseva u građanstvu i vojsci od 1921. do aprila 1930.
} 
kurseva bio je osposobljavanje stanovništva za dalje samostalno prosvećivanje i usavršavanje. Na kurseve su primani svi nepismeni građani i građanke bez obzira na zanimanje i osposobljavani su u čitanju, pisanju i računanju. Kursevi su predviđali i opismenjavanje stranih državljana ukoliko u zemlji provedu najmanje godinu dana. Nastava je organizovana od novembra do marta naredne godine, prvenstveno da se ne bi remetili radovi u polju, a ukoliko u pojedinim mestima uslovi dozvoljavaju, mogla je trajati i čitavu školsku godinu. Predviđen broj đaka bio je između 10 i 50. Postojala je i mogućnost privatnih kurseva, s obavezom da budu pod nadzorom prosvetnih vlasti. ${ }^{24}$

Nekoliko godina kasnije precizirani su uslovi koji pretpostavljaju opismenjavanje mladih čije je vreme za osnovno školovanje prošlo, tačnije stanovništvo od navršene 11 . do navršene 20 . godine. Prema prilikama i po želji na kurseve su primane i starije osobe. Kursevi su mogli biti držani u svim prikladnim prostorijama, osim u kafanama. Ukoliko postoje uslovi za držanje nastave u najbližoj osnovnoj školi, obavljala bi se u vanredno vreme. Nastavu bi izvodili učitelji i učiteljice, ili bilo koje pismeno lice od koga se očekivala „ozbiljnost, moralno vladanje, sprema i ljubav za rad oko vođenja tečaja“. Sredstva za rad, potrebne knjige i pribor za pisanje obezbedile bi opštine samostalno, ili uz pomoć Ministarstva. Definisani su i domeni rada, odnosno pored čitanja, pisanja i računanja, polaznici su morali da nauče nazive mesta u svom kraju, državne granice, imena susednih zemalja, glavne gradove u pokrajinama, reke i luke na Jadranu. Na kraju svakog kursa organizovan je ispit kome su u svojstvu komisije prisustvovali članovi školskog odbora, školski nadzornik i predsednik opštine. ${ }^{25}$ Iz navedenog se primećuje i angažovanje vanškolskih lica u organizovanju i izvođenju kurseva. U skladu sa osnovnom idejom o opismenjavanju, zamisao Ministarstva je bila da uključi sve relevantne institucije na lokalnom i oblasnom nivou, kako bi se osigurala podrška, naročito materijalna. Osnivanje prosvetnih odbora predviđalo je uključivanje vojske, crkve, kao i opštinskih organa. Prema tome, pored školskih nadzornika, u odbore su ulazili i lokalni lekari, inženjeri, predsednici skupština, najstariji oficiri u garnizonu, ili njihovi izaslanici i predstavnici crkve. ${ }^{26}$ Svakog obučenog analfabetu, u građanstvu ili vojsci, evidentirale su nakon toga matične opštine $\mathrm{i}$ unosile u svoje spiskove $\mathrm{i}$ javne isprave. ${ }^{27}$

Organizovanje i pohađanje kurseva regulisano je u skladu sa Zakonom o narodnim školama. Predviđene su mere za neuredno pohađanje kursa od strane slušalaca, a ustanovljen je i profil predavača u odsustvu školovanih učitelja. Ukoliko ne postoji mogućnost angažovanja aktivnih ili penzionisanih učitelja, predavanja su mogli izvoditi sveštenici, studenti, svršeni učenici poljoprivrednih škola i druga lica sa odgovarajućom stručnom spremom. Utvrđen je nastavni plan koji je obuhvatao narodni jezik 6 časova nedeljno, račun 3 časa, geografiju

\footnotetext{
${ }^{24}$ AJ, 66-2215, Pravila o uređenju kurseva za nepismene o. n. br. 50603 od 5. novembra 1921.

${ }^{25}$ Isto, Naredba Ministarstva prosvete o širenju pismenosti u narodu br. 1325/III od 4. januara 1926.

${ }^{26}$ AJ, 66-2204, Pravila o organizovanju i radu odbora za narodno prosvećivanje o. n. br. 27901 od 6. jula 1921.

${ }^{27}$ Служббени војни лист, 1930, Београд 1931, 2599-2601.
} 
sa istorijom 3 časa i higijenu 2 časa. Po nastavnom programu iz jezika je učeno gradivo za prvi razred osnovne škole, iz matematike pisanje brojeva do $1.000 \mathrm{i}$ osnovne računske radnje sa celim brojevima. Gradivo iz geografije predviđalo je državne granice, zemljište, glavne reke, jezera, stanovništvo po broju, veri, narodnosti i zanimanju, kao i upravnu podelu zemlje. Iz istorije akcenat je dat na upoznavanje sa idejom jugoslovenstva i savremenu istoriju, tačnije period XIX i početka XX veka. Higijena bi upoznala kursiste sa delovima ljudskog tela, čuvanjem zdravlja, umerenošću u jelu i piću, uređenjem kuće i dvorišta, a naročito sa suzbijanjem praznoverica. ${ }^{28}$

Sa uključivanjem vojske u izvođenje analfabetskih kurseva krenulo se uporedo kao u građanstvu. Uloga vojske kao značajnog nosioca modernizacije u društvu predviđala je i angažovanje na polju kulturnog uzdizanja stanovništva. Savremena vojna organizacija sa naprednim tehnologijama pretpostavljala je makar elementarnu pismenost svojih pripadnika. ${ }^{29} \mathrm{~S}$ obzirom na činjenicu da je čitava muška populacija (fizički i mentalno zdrava) prolazila kroz vojnu organizaciju, s pravom se računalo na aktivnu ulogu komandi i jedinica u elementarnom opismenjavanju regruta. Kao dobre osobine kurseva u vojsci možemo navesti, pre svega, odsustvo svakog vida nediscipline kod kursista, kao i mogućnost da se nastava izvodi tokom cele godine. Lošu stranu, pored nemogućnosti opismenjavanja ženske populacije, predstavljale su teškoće oko iznalaženja slobodnog vremena, s obzirom na angažovanje vojnika na redovnim dužnostima, tako da bi izvođenje nastave iz pismenosti išlo na štetu stručne obuke.

U saradnji sa Ministarstvom prosvete, Ministarstvo vojske i mornarice je sebi postavilo cilj da, budući da je vojska pogodno tle za opismenjavanje, na tom polju obuči što više regruta. Planirano je što je moguće više kurseva u okviru jedinica, uzimajući u obzir ostale aktivnosti. Od oslobođenja do kraja 1930. godine na održavanje analfabetskih kurseva u građanstvu i vojsci, kao i na rad domaćičkih škola utrošeno je 25.189.380 dinara, a za podizanje školskih zgrada 98.846.380 dinara. ${ }^{30}$ Broj održanih kurseva i obučenih analfabeta najbolje se vidi iz sledeće tabele: ${ }^{31}$

${ }^{28}$ AJ, 66-2215, Naređenje Ministarstva prosvete o organizovanju analfabetskih kurseva o. n. br. 82600 od 11. novembra 1930.

${ }^{29} \mathrm{O}$ ulozi vojske u modernizaciji i podizanju kulturnog nivoa stanovništva opširnije videti: Mile Bjelajac, Vojska Kraljevine SHS/Jugoslavije 1922-1935 (Beograd: Institut za noviju istoriju Srbije, 1994), 268-282; Isti, „Vojska kao faktor modernizacije“, u: Srbija u modernizacijskim procesima XX veka, ur. Latinka Perović i dr., (Beograd: Institut za noviju istoriju Srbije, 1994), 355-359; Светислав Милосављевић, $O$ моралном, научном и физичком васпитағу офищира по командама (Београд, 1926); Илија Панић, „Војска и опште образовање наше школске омладине“, Ратник, XI-XII, (1927), 87-95; К., „Вредност и циљ моралне снаге“, Ратник, X, (1929), 117-124; Бајо Станишић, „Морално васпитање војника“, Ратник, VIIVIII, (1937), 113-122, 105-112; Далибор Велојић, „Улога војске у модернизацији града (нишки гарнизон 1918-1941)“, Војно-историјски гласник, бр. 1, (2012), 71-88.

30 AJ, 38-64-169, Razvoj analfabetskih kurseva u građanstvu i vojsci od 1921. do aprila 1930.

${ }^{31}$ Isto. 


\begin{tabular}{|c|c|c|c|}
\hline Godina & & \multirow{2}{*}{$\begin{array}{r}\text { Broj kurseva } \\
194 \\
\end{array}$} & \multirow{2}{*}{$\begin{array}{l}\begin{array}{l}\text { Broj obučenih } \\
\text { analfabeta }\end{array} \\
4.140\end{array}$} \\
\hline 1921. & građanstvo & & \\
\hline & vojska & 35 & 896 \\
\hline & ukupno & 229 & 5.035 \\
\hline \multirow[t]{3}{*}{1922.} & građanstvo & 189 & 3.948 \\
\hline & vojska & 71 & 2.130 \\
\hline & ukupno & 260 & 6.078 \\
\hline \multirow[t]{3}{*}{1923.} & građanstvo & 162 & 4.753 \\
\hline & vojska & 75 & 2.738 \\
\hline & ukupno & 237 & 7.491 \\
\hline \multirow[t]{3}{*}{1924.} & građanstvo & 216 & 5.920 \\
\hline & vojska & 162 & 3.618 \\
\hline & ukupno & 378 & 9.538 \\
\hline \multirow[t]{3}{*}{1925.} & građanstvo & 807 & 12.129 \\
\hline & vojska & 469 & 12.064 \\
\hline & ukupno & 1.276 & 24.193 \\
\hline \multirow[t]{3}{*}{1926.} & građanstvo & 169 & 5.255 \\
\hline & vojska & 38 & 3.112 \\
\hline & ukupno & 207 & 8.367 \\
\hline \multirow[t]{3}{*}{1927.} & građanstvo & 150 & 9.765 \\
\hline & vojska & 199 & 5.963 \\
\hline & ukupno & 349 & 15.728 \\
\hline \multirow[t]{3}{*}{1928.} & građanstvo & 225 & 10.120 \\
\hline & vojska & 82 & 6.582 \\
\hline & ukupno & 307 & 16.702 \\
\hline \multirow{3}{*}{$\begin{array}{l}\text { 1929. do } \\
\text { 1. aprila } \\
1930 .\end{array}$} & građanstvo & 198 & 7.700 \\
\hline & vojska & 282 & 14.697 \\
\hline & ukupno & 480 & 22.397 \\
\hline
\end{tabular}

Ukupno je u ovom periodu u građanstvu održano 2.310 kurseva i obučeno 63.730 analfabeta, prema 1.413 kurseva u vojsci sa 51.799 obučenih. Iz navedenog se vidi da angažovanje na opismenjavanju u vojsci ni u kom slučaju nije zaostajalo za onim $u$ građanstvu, naročito ako se imaju $u$ vidu ostale aktivnosti (obuka regruta, stražarska služba, vojne vežbe, odlazak na teren) koje su u jedinicama i komandama imale prioritet.

Uspeh u nastavi i visok procenat osposobljenih mogu se objasniti ozbiljnošću trupnih starešina, budući da su kursevi nalazili svoje mesto u sklopu redovne obuke $u$ vojsci. Kao ilustraciju navešćemo podatke iz pojedinih garnizona. U bolničkoj četi Vrbaske divizijske oblasti u 1921. godini od 69 nepismenih kurs su završila 63 vojnika, 28 bilo je odličnih, 20 vrlo dobrih i 15 dovoljnih. ${ }^{32} \mathrm{Za} 29$. pešadijski puk iz sastava Zetske divizijske oblasti u izveštaju za 1924. godinu stoji da je bilo 348 nepismenih, od kojih je 198 obučeno u potpunosti, a 77 je samo naučilo da čita. ${ }^{33} \mathrm{U}$ 32. pešadijskom puku iz Mostara na kursu koji je trajao od 1. aprila do 13. jula 1926. od 130 nepismenih svi su naučili pisanje slova, reči i

\footnotetext{
${ }^{32} \mathrm{AJ}, 66-2234$

${ }^{33}$ AJ, 66-2238.
} 
celih rečenica, kao i pisanje imena i prezimena. ${ }^{34} \mathrm{U}$ aleksinačkom 1. divizionu 10. artiljerijskog puka od maja do avgusta 1929. od 84 opismenjeno je 80 vojnika. ${ }^{35}$

Međutim, nakon dobijenih izveštaja iz jedinica, već na početku ocenjeno je da rad na opismenjavanju regruta može biti daleko uspešniji. Kao teškoće navedeni su veliki unutrašnji rashodi, rasturenost po trupama u pogledu dislokacije, kao i za početak dvadesetih godina, specijalni uslovi na teritoriji III armijske oblasti. Primer za ovo je skopski 7. konjički puk, gde je od 1. oktobra 1923. do 10. januara 1924. održana nastava sa 120 analfabeta, ali usled vanrednih zadataka nije bilo završnog ispita. ${ }^{36}$ Nedostatak stručnog kadra je takođe predstavljao problem. Učitelji su se nerado javljali za ovaj posao, jer se kasnilo sa honorarima. Pored toga, loša situacija sa nastavnim sredstvima zahtevala je kredite, tako da se dolazilo u situaciju da pojedine komande, pa i pojedini imućniji vojnici sami nabavljaju knjige. Tokom 1921. godine u izveštaju Savske divizijske oblasti ukupno je evidentirano 1.137 nepismenih vojnika. Kod Ministarstva prosvete trebovano je po 1.200 bukvara, tablica i olovaka, kao i 10 velikih drvenih tabli. ${ }^{37}$

Nije nevažna ni činjenica da je u jedinicama bilo znatnog broja neslovena, koji često nisu ni znali jezik, a nastava nije trajala preko cele godine. ${ }^{38}$ Vrbaska divizijska oblast je 1923. godine sprovela u 26. pešadijskom puku obuku u opismenjavanju, ali su, usled nedostatka učitelja, nastavu držali oficiri i podoficiri, nakon kratke metodske obuke. U 33. pešadijskom puku od 209 nepismenih kurs su završila 82. Kao razlog malog broja uspešnih navodi se dosta regruta rumunske nacionalnosti koji nisu znali jezik, kao i nesposobnost ostalih da za kratko vreme savladaju gradivo. U 44. pešadijskom puku od 340 polaznika završila su sa uspehom 142 . Za 25. artiljerijski puk kao opravdanje za mali broj opismenjenih navodi se veliki broj Arnauta koji nisu znali jezik. ${ }^{39}$ Od regruta koji su decembra 1921. došli u Slavonsku Požegu u 43. pešadijski puk 50\% bilo je nepismenih, od čega 30\% Arnauta koji nisu znali srpskohrvatski. Od ovog broja Arnauta $60 \%$ njih je naučilo jezik. ${ }^{40} \mathrm{U} 16$. artiljerijskom puku u Ljubljani u periodu od 1. maja do 30. jula 1925. od 87 polaznika opismenjeno je 84, a od 16. aprila do 7. jula od 109 opismenjen je 91 vojnik. Zanimljivo je da na spisku u rubrici napomena za vojnike koji nisu završili kurs stoji bolovanje, nagrada, odsustvo i, bez dodatnog objašnjenja - Arnaut. ${ }^{41}$

Data je zamerka u drugom izveštaju iz 1924. godine da same komande ne vode računa o izvođenju nastave, a naveden je i primer gde je od 130 prijavljenih vojnika u jedinici samo 15 njih pohađalo nastavu. ${ }^{42} \mathrm{U}$ sklopu mera za

\footnotetext{
${ }^{34} \mathrm{AJ}, 66-2234$.

${ }^{35}$ Isto.

${ }^{36}$ AJ, 66-2252.

${ }^{37}$ AJ, 66-2259.

${ }^{38}$ AJ, 66-2234, Izveštaj Ministarstva vojske i mornarice, opšteg vojnog odeljenja đeneralštabnog odseka pov. f. đ. br. 1954 od 19. februara 1923.

${ }^{39}$ AJ, 66-2215.

${ }^{40}$ AJ, 66-2247.

${ }^{41}$ AJ, 66-2242.

42 Isto, Izveštaj operativnog odseka đeneralštabnog odeljenja Ministarstva vojske i mornarice ministru prosvete đ. br. 36.936 od 15. oktobra 1924.
} 
otklanjanje nedostataka naređeno je, pre svega, da nastava bude obavezna i traje tokom cele godine, a da se izbegne slanje nepismenih regruta u rashod, povećanje honorara učiteljima i odobrenje kredita za nabavku sredstava za izvođenje nastave. Predviđena suma iznosila bi za svaki pešadijski puk, komandu inžinjerije, auto komandu, vazduhoplovnu i železničku komandu po 7.500 dinara, za svaki konjički i artiljerijski puk po 3.500 dinara, za komande armijskih oblasti po 10.000, za komande divizijskih oblasti po 2.000 dinara, sem za Dunavsku koja je dobila 5.000 i za komande konjičkih divizija po 1.000 dinara. $^{43}$

Uzevši u obzir ovakve i slične izveštaje, očigledna je namera Ministarstva i čitave Vlade da se znatno ozbiljnije angažuju na polju opismenjavanja regruta. $^{44} \mathrm{U}$ izveštaju Ministarstva prosvete iz 1931. godine navodi se, između ostalog, i veliki procenat nepismenog stanovništva, naročito u siromašnim krajevima. Ministarstvo je intenzivno radilo na smanjenju tog broja organizovanjem kurseva u građanstvu i vojsci. Očigledno je da ovakav rad nije dao zadovoljavajuće rezultate, pa je bilo neophodno da se sistematizuje i dobije zakonsku podlogu. Predlog za vojsku bio je u domenu trajanja kurseva, broja časova i načina rada. Prema tome, školski nadzornici bili su u obavezi da, odmah nakon dolaska regruta u kasarne (15 dana od dolaska), u sporazumu sa nadležnim starešinama, pristupe organizovanju kurseva. Kursevi bi u pešadiji, konjici i artiljeriji trajali tri i po, u vazduhoplovstvu tri, a u inžinjeriji četiri meseca i mogli su biti održavani preko cele godine. $^{45} \mathrm{Za}$ obuku kod jedinica vazduhoplovstva, koje su regrute primale jednom godišnje u novembru, napravljen je izuzetak. Budući da je osnovna vojna obuka trajala tri meseca (koliko i analfabetski kursevi), nakon čega su vojnici slati $\mathrm{u}$ različite jedinice na stručni deo, postavio se problem njihovog okupljanja i zajedničke nastave. Prihvaćen je predlog koji je potekao od 3. vazduhoplovnog puka 1934. godine, a predviđao je početak analfabetskih kurseva u vazduhoplovstvu odmah po dolasku regruta, naporedo sa osnovnom obukom. ${ }^{46}$

Nastava se u svim jedinicama izvodila po sedam časova sedmično: nedeljom po dva časa, a ostalim danima, sem subote, po jedan čas. U slučaju potrebe komandanti su mogli kod pešadijskih i inžinjerijskih jedinica povećati broj časova na deset nedeljno, a kod vazduhoplovstva smanjiti na pet. Kursevi su bili obavezni za sve nepismene vojnike, kao i za samouke i one koji su ih već pohađali, ali neuspešno. Utvrđen je i maksimalan broj vojnika do 70 po jednoj grupi (najidealnije 50-60), a nadležnim starešinama dat je zadatak nabavke udžbenika i sređivanja učionica. Sugerisano je vojnim vlastima da u toku trajanja kursa ne koriste nepismene vojnike za druge poslove, kao i da se odlože sve prekomande. Nakon završetka nastave organizovan bi bio ispit kome su prisustvovali školski nadzornik, kao predsednik komisije, komandir dotične čete (baterije, eskadrona, odeljenja) i jedan

${ }^{43}$ Isto, Izveštaj Ministarstva vojske i mornarice, opšteg vojnog odeljenja đeneralštabnog odseka pov. f. đ. br. 1954 od 19. februara 1923.

${ }^{44}$ Ivan Becić navodi da je u uslovima prikrivene diktature i ekonomske krize Vlada tražila određen uspeh i mogućnost da ga postigne na polju opismenjavanja. И. Бецић, н. д., 210.

${ }^{45}$ AJ, 66-204, Izveštaj Ministarstva prosvete o. n. br. 43624 od 9. juna 1931; AJ, 66-2234, Izveštaj Ministarstva prosvete o. n. br. 52651 od 14. avgusta 1931.

${ }^{46}$ AJ, 66-273, Komanda aerodroma - komandi 3. vazduhoplovnog puka br. 1872 od 4. avgusta 1934. 
mlađi starešina, kao član. ${ }^{47} \mathrm{U}$ izuzetnim slučajevima umesto školskog nadzornika mogao je ispitu prisustvovati i viši trupni oficir, kao što je organizovano u 19. pešadijskom puku u Kragujevcu 1928. godine, kada je tu funkciju obavljao komandant bataljona. ${ }^{48}$ Nastavni plan bi obuhvatio, kao i u građanstvu, narodni jezik 6 časova, račun 3 časa i geografiju sa istorijom 3 časa nedeljno. ${ }^{49}$ Primećuje se da u nastavni plan i program nije uvrštena higijena, pošto su predavanja iz ove oblasti bila organizovana zasebno i izvodili su ih trupni lekari i oficiri.

Tridesetih godina aktivnosti na opismenjavanju vojnika, kako se iz navedenog vidi, poprimile su daleko ozbiljnije razmere. Stvaranje zakonske podloge i motivisanje stručnog kadra rezultiralo je mnogo većim napretkom kurseva u vojsci u odnosu na civilstvo. Podaci iz konkretnih jedinica ilustruju opšte stanje na polju opismenjavanja. Izveštaji Drinske banovine za 1932/33, na primer, govore o skoro trostruko većem broju kurseva u vojsci u odnosu na građanstvo.$^{50} \mathrm{Za}$ grad Beograd se u 1933. godini navodi da kurseva u građanstvu nije bilo, dok se u vojsci održavaju redovno. Pešadijski puk kraljeve garde je 1933. (29. maj - 14. septembar) od 380 kursista imao samo 9 sa negativnom ocenom, dok je konjički puk imao 93,8\% uspešnih. ${ }^{51} \mathrm{U} 6$. vazduhoplovnom puku u Zemunu od 73 analfabeta opismenjeno je 62. ${ }^{52} \mathrm{U}$ izveštaju za Slavonski Brod iz 1932. godine stoji da je u građanstvu neisplativo držati kurseve, jer ni u jednom mestu nema dovoljno nepismenih, dok je u srezu Stolac vojska isključivi nosilac opismenjavanja, koje se godišnje povećava za $1,2 \%{ }^{53}$ U Rajlovcu je 1937. godine od 73 nepismena opismenjen 71 vojnik. ${ }^{54}$ Kragujevački 3. samostalni artiljerijski divizion je u 1938. godini obučio 68 vojnika od ukupno 75 nepismenih. ${ }^{55} \mathrm{U}$ 6. vazduhoplovnoj bazi od 90 nepismenih 1939. godine ispit je položilo $85 .{ }^{56}$ Artiljerijski puk V

\footnotetext{
${ }^{47}$ AJ, 66-2204, Izveštaj Ministarstva prosvete o. n. br. 43624 od 9. juna 1931; AJ, 66-2234, Izveštaj Ministarstva prosvete o. n. br. 52651 od 14. avgusta 1931.

${ }^{48}$ AJ, 66-2241.

${ }^{49}$ Narodni jezik je obuhvatao gradivo za prvi razred osnovne škole. Naročitu pažnju obraćali su predavači na metode glasovnog i slogovnog iščitavanja, bez sricanja. Po savlađivanju čitanja prelazilo se na narodne pesme i pripovetke. Iz računa, pored upoznavanja sa brojevima do 1.000 i osnovnih računskih operacija, učene su mere za dužinu i za vreme. Geografija je obuhvatala razumevanje karte, ime države, reke, jezera, more, stanovništvo po broju, veri i nacionalnosti, glavna mesta, prava i dužnosti građana. Istorija je predviđala sledeće teme: nacionalno buđenje Jugoslovena i borbe za slobodu; Kočina krajina, dahije, Prvi i Drugi srpski ustanak; Vlada kneza Miloša i Mihaila; Narodni preporod: Valentin Vodnik, Jernej Kopitar, Vuk Karadžić i Ljudevit Gaj; Knez Aleksandar Karađorđević; Jugosloveni u pokretu 1848. godine; Ratovi za nezavisnost Srbije i Crne Gore, okupacija Bosne i Hercegovine; Balkanski i Prvi svetski rat; Jugoslovenski dobrovoljci; Oslobođenje i ujedinjenje i uređenje Kraljevine Jugoslavije. Kralj Aleksandar Karađorđević. AJ, 66-2204, Izveštaj Ministarstva prosvete o. n. br. 43624 od 9. juna 1931; AJ, 66- 2234, Izveštaj Ministarstva prosvete o. n. br. 52651 od 14. avgusta 1931.

${ }^{50}$ AJ, 66-2209, Izveštaj Drinske banovine o narodnom prosvećivanju.

${ }^{51}$ И. Бецић, н. д., 211.

${ }^{52}$ AJ, 66-2211, Školski nadzornik za grad Beograd - Ministarstvu prosvete br. 1523 od 19. jula 1933.

${ }^{53}$ AJ, 66-2213, Izveštaji Ministarstvu prosvete.

${ }^{54}$ AJ, 66-2480.

${ }^{55} \mathrm{AJ}, 66-2476$.

${ }^{56}$ AJ, 66-2473.
} 
armijske oblasti u Nišu je u 1940. godini imao 100\% opismenjenih, što je slučaj i sa 3. samostalnim divizionom teške artiljerije. Na teritoriji Moravske divizijske oblasti opismenjeno je iste godine $84,35 \%$ analfabeta, a samo u 16 . pešadijskom puku 73\%. ${ }^{57}$ Izuzetak je 1. pionirski puk u kojem je 1939/1940. izostala obuka u opismenjavanju, usled nedostatka kredita. ${ }^{58}$

Tokom 1939. došlo je do toga da u vojsci bude dva puta više kurseva nego u građanstvu. U prilog tome navešćemo podatke po banovinama iz istraživanja Momčila Isića: ${ }^{59}$

\begin{tabular}{|l|r|r|r|r|}
\hline \multirow{2}{*}{$\begin{array}{l}\text { Banovine } \\
\text { i Beograd })\end{array}$} & \multicolumn{2}{|c|}{ Broj kurseva } & \multicolumn{2}{c|}{ Broj analfabeta } \\
\cline { 2 - 5 } Beograd & $\mathrm{u}$ vojsci & \multicolumn{1}{c|}{$\mathrm{u}$ građanstvu } & u vojsci & \multicolumn{1}{c|}{ u građanstvu } \\
\hline Vardarska & 36 & 1 & 2.115 & 42 \\
\hline Vrbaska & 40 & 39 & 1.820 & 1.645 \\
\hline Dravska & 10 & 22 & 780 & 752 \\
\hline Drinska & 34 & - & 1.892 & - \\
\hline Dunavska & 33 & 25 & 2.231 & 1.204 \\
\hline Zetska & 58 & 1 & 3.355 & 43 \\
\hline Moravska & 37 & 5 & 1.971 & 187 \\
\hline Primorska & 39 & 2 & 2.116 & 50 \\
\hline Savska & 26 & 33 & 1.597 & 1.304 \\
\hline Ukupno & 71 & 45 & 4.146 & 1.287 \\
\hline
\end{tabular}

Novčana izdvajanja su, međutim, bila daleko skromnija nakon ekonomske krize. U budžetu za 1931. godinu predviđeno je za banovine po 100.000 dinara, izuzev Drinske koja je dobila 290.000 dinara za održavanje kurseva. Narednih godina ta brojka se smanjila, pa je iznosila i 80.000 dinara. ${ }^{60} \mathrm{Za}$ godinu 1938. zahtevano je ukupno 1.750.000 dinara, a odobrena je polovina, odnosno 875.000 za analfabetske kurseve. Ministarstvo prosvete je od nadležnih komandi tražilo održavanje većeg broja kurseva, ali usled ograničenih kredita to nije ostvareno. Od napred navedene sume na Beograd je potrošeno 75.000, Banja Luku 90.000, Zagreb, 140.000, Ljubljanu 70.000, Niš 90.000, Novi Sad 10.000, Cetinje 80.000, Sarajevo 75.000, Skoplje 90.000 i Split 65.000 dinara. $^{61}$ Narednih godina zahtevana suma je odobrena i podeljena po banovinskim centrima na sledeći način: ${ }^{62}$

${ }^{57}$ Vojni arhiv (VA), popisnik (p.) 17, kutija (kut.) 576, fascikla (fasc.) 3, dokument (dok.) 33, 35,38 .

${ }^{58}$ Od 1.067 regruta primljenih u 1. pionirski puk u januaru 1940. bilo je 29,33\% nepismenih, a od 433 primljena u puk za potrebe posadnih četa u novembru 1939. nepismenih je bilo $6,23 \%$. Nastava se nije izvodila, prema objašnjenju, usled nedostatka kredita i nedovoljnog broja starešina. VA, p. 17, kut. 397, fasc. 13, dok. 16, 17.

59 Tabela preuzeta iz: Момчило Исић, „Писменост у Србији у првој половини XX века“, Токови историје, бр. 1-2, (1993), 100.

${ }^{60}$ AJ, 66-2208, 66-2209, Izveštaji po banovinama.

${ }^{61}$ AJ, 66-564, Izveštaj Ministarstva prosvete i. br. 19448 od 28. maja 1938.

${ }^{62}$ AJ, 66-2483, Izveštaj Ministarstva prosvete za odobren kredit za analfabetske kurseve. 


\begin{tabular}{|l|r|r|}
\hline Banovinski centri (i Beograd) & $1938 / 1939$. & $1939 / 1940$. \\
\hline Beograd & 150.000 & 150.000 \\
\hline Banja Luka & 180.000 & 120.000 \\
\hline Zagreb & 280.000 & 340.000 \\
\hline Niš & 180.000 & 110.000 \\
\hline Ljubljana & 140.000 & 140.000 \\
\hline Novi Sad & 200.000 & 210.000 \\
\hline Cetinje & 160.000 & 150.000 \\
\hline Sarajevo & 150.000 & 150.000 \\
\hline Skoplje & 180.000 & 220.000 \\
\hline Split & 130.000 & 150.000 \\
\hline Ukupno dinara & $\mathbf{1 . 7 5 0 . 0 0 0}$ & $\mathbf{1 . 7 4 0 . 0 0 0}$ \\
\hline
\end{tabular}

Odobreni krediti isplaćivani su hronološkim redom prijavljivanja, odnosno rodovi vojske koji su regrute primali u aprilu mogli su svojim trebovanjima iskoristiti veći deo novčanih sredstava. Usled takve prakse, nastava kod jedinica vazduhoplovstva (koje su regrute primale jednom godišnje u novembru), trpela je zbog nedostatka kredita. Intervencijom kod Ministarstva vojske i mornarice izdejstvovano je da se svake budžetske godine rezerviše od raspoloživog kredita suma potrebna za obuku po 120 regruta za svaki vazduhoplovni puk i 50 za vazduhoplovnotehnički zavod, vazduhoplovne škole gađanja, 1. balonski bataljon i 261. samostalnu grupu. Po prijemu regruta krediti bi se trebovali i konačno bili odobravani. ${ }^{63}$

Nakon razmatranja organizacionih i finansijskih problema potrebno je razmotriti i socijalni aspekt, tačnije poreklo nepismenih vojnika. Shodno procentualnom iznosu u građanstvu, u vojsci je tokom čitavog međuratnog perioda takođe zapažen veći broj analfabeta koji dolaze iz siromašnijih i zabačenih krajeva. Kao najugroženiji krajevi uglavnom su navođena mesta Vardarske, Moravske i Vrbaske banovine. Ilustracije radi, u 45. pešadijskom puku u Mariboru 1924. godine u 1. i 2. bataljonu iz Moravskog okruga bilo je 19 nepismenih, Mostara 12, Tuzle 8, dok je u 3. bataljonu iz Krajinskog okruga bilo 17, Timočkog 7, Križevačkog 6 i Tuzlanskog 3. ${ }^{64}$ U 20. pešadijskom puku u Negotinu iste godine iz Timočkog okruga bilo je 14 nepismenih, Požarevačkog 7, Krajinskog 3, iz Čakovca 5, Moravskog 3, Pančevačkog 3, Karlovačkog 4, Ljubljanskog 1, Bitoljskog 5, Zagrebačkog 2, Banjalučkog 2, iz Bačke 3 i Varaždina 1. ${ }^{65}$ Pontonirski bataljon u Šapcu je evidentirao 1926. godine od ukupno 58 nepismenih iz starih granica Srbije 32 i iz Južne Srbije 18. ${ }^{66}$ Delovi 24. pešadijskog puka smešteni u garnizonu Novi Pazar primili su 1928. godine 41 nepismenog regruta iz okoline Požarevca, dok su iz okoline Zagreba bila dvojica i Maribora jedan. Auto puk I armijske oblasti je 1932. trećinu nepismenih imao iz skopskog vojnog okruga. ${ }^{67} \mathrm{U}$ garnizonu u Gornjem Milanovcu registrovan je 1930. godine najveći broj nepi-

\footnotetext{
${ }^{63}$ AJ, 66-273, Komanda vazduhoplovstva Ministarstvu vojske i mornarice v. đ. br. 3732 od 1. aprila 1934 .

${ }^{64}$ AJ, 66-2242.

${ }^{65} \mathrm{AJ}, 66-2245$.

${ }^{66} \mathrm{AJ}, 66-2254$.

${ }^{67}$ AJ, 66-2246, 2247.
} 
smenih iz okoline Vranja i Kičeva. Đakovički 56. pešadijski puk je naredne godine imao najveći procenat nepismenih iz pirotskog okruga. ${ }^{68} \mathrm{U} 36$. pešadijskom puku iz Varaždina navodi se da su svi polaznici kursa u 1931. godini iz Vardarske i Moravske banovine, iz srezova Preševskog, Rasinskog i Žičkog. ${ }^{69}$

Za godine 1933. i 1934. u jedinicama kraljeve garde zabeležen je najveći procenat nepismenih iz Vardarske, Moravske i Drinske banovine. ${ }^{70}$ Jedinice 2. pešadijskog puka u Beogradu beleže u 1938. godini od 77 polaznika kursa najviše Albanaca iz okoline Gnjilana, Vučitrna, Prizrena i Đakovice. ${ }^{71} \mathrm{U}$ izveštaju 1. pionirskog puka iz Niša za 1940. godinu navodi se da su iz zagrebačkog vojnog okruga od ukupno 100 poslatih regruta nepismena bila dvojica (2\%), iz Varaždinskog od 51 nepismena četvorica $(7,8 \%)$, somborskog od 32 nepismen samo jedan (4,3\%), ali da je, s druge strane, okrug Travnik od 29 regruta imao 23 nepismena (79,31\%), Tuzla od 50 nepismen 21 (42\%), Kosovska Mitrovica od 64 nepismenih 27 (41\%), Prizren od 65 nepismenih 48 (73,84\%), Priština od 91 nepismena 62 $(68,13 \%)$. U posadnim četama ovog puka od 433 regruta uzetih sa teritorija Hrvatske i Slovenije (vojni okruzi Celje, Ljubljana, Maribor, Varaždin, Karlovac i Otočac) bilo je nepismeno $27 .{ }^{72}$ Ovim primerima jasno se pokazuje koliko se socijalna struktura države odslikavala u vojsci, ali, uzevši u obzir broj održanih kurseva i broj opismenjenih regruta, zapaža se i koliko je vojna organizacija bila od značaja za podizanje obrazovnog i kulturnog nivoa stanovništva u zaostalim krajevima.

Aktuelan problem tokom čitavog međuratnog perioda bio je nedostatak stručnog kadra za obuku vojnika. Opšti nedostatak učitelja odrazio se i na stanje u vojsci, tako da su jedinice i komande morale iznalaziti načine za angažovanje predavača. Kako je navedeno, Ministarstvo prosvete je propisalo da nastavu sa analfabetama mogu izvoditi sva pismena lica koja za to prođu obuku, predviđalo se da i u vojsci taj posao mogu obavljati oficiri, sveštenici, pa i podoficiri. U 3. konjičkom puku u Subotici 1924. godine nastavu su izvodili vojni sveštenici i to pravoslavni, katolički i muslimanski, a u Šapcu je 1926. godine u okviru nastave učena i veronauka. ${ }^{73}$ Niški 3 . divizion teške artiljerije takođe je angažovao vojnog sveštenika. ${ }^{74}$ U 9. artiljerijskom puku od 51 vojnika završila su 43, od toga 15 sa odličnim uspehom, 20 vrlo dobrih i 8 dobrih. Ovde je nastavu sa uspehom izvodio pukovski narednik, koji je kasnije predložen za stimulativne mere. $^{75}$ Često su iznošene primedbe da su, usled nedostatka stručnog kadra, učitelji primoravani da preuzmu više slušalaca od predviđenog broja, što je išlo na štetu kvaliteta nastave. O angažovanju učiteljica gotovo da i nema podataka, sem primedbi da iz ,familijarnih razloga“ nisu u mogućnosti da po kasarnama drže predavanja. Već 1921. godine Ministarstvo vojske i mornarice predvidelo

\footnotetext{
${ }^{68} \mathrm{AJ}, 66-2238,2239$.

${ }^{69}$ AJ, 66-2258.

${ }^{70}$ И. Бецић, н. д., 212-213.

${ }^{71}$ AJ, 66-473.

${ }^{72}$ VA, p. 17 , kut. 397 , fasc. 13 , dok. $17 / 6$.

${ }^{73}$ AJ, 66-2254.

${ }^{74} \mathrm{AJ}, 66-2245$.

${ }^{75} \mathrm{AJ}, 66-2215$.
} 
je u nastavnom planu za rodove i službe obuku u opismenjavanju. Od Ministarstva prosvete traženo je da obezbedi dovoljno učitelja iz mesnih osnovnih škola čiji bi izbor izvršili komandanti dotičnih jedinica i školski nadzornici. Honorare učiteljima odredilo bi Ministarstvo prosvete. ${ }^{76}$ Strategija na duži rok predviđala je i stalne učitelje koji bi u kasarnama konstantno vršili obuku. ${ }^{77}$ Ovakva praksa očigledno nije dala željene rezultate, što se vidi iz izveštaja za 1939. godinu u kome je navedeno da samoinicijativni izbor učitelja od strane komandanata šteti uspehu opismenjavanja i rezultira velikim procentom neobučenih. ${ }^{78}$

Razlozi za nezainteresovanost učitelja su kod pojedinih bili nedostatak vremena i neusaglašenost sa redovnom nastavom, ali glavni problem predstavljale su dnevnice. Dvadesetih godina iznos dnevnica u građanstvu je varirao i kretao se od 40 do 60 dinara po obučenom analfabeti. Razlog ovome treba tražiti u teškoćama na koje se nailazilo u siromašnijim krajevima, gde uslovi nisu zadovoljavali minimum potreban za rad. Tako je već 1920. godine propisana nagrada za Veles, okolinu Prizrena, Prištine, Skoplja, Štipa u iznosu od 60 dinara, dok se za Kragujevac, Niš, Beograd, Zaječar, mesta u Zetskoj banovini kretala od 40 do 50 dinara po obučenom kursisti. ${ }^{79} \mathrm{U}$ vojsci je ta cifra iznosila 40 dinara, s tim da se i oficirima koji rade kao predavači umesto učitelja isplaćuje isti iznos, dok bi podoficirima, ukoliko budu angažovani, isplaćivano po 5 dinara po obučenom vojniku. ${ }^{80}$ Od strane samih komandi predlagano je povećanje iznosa nagrade učiteljima, kao i uvođenje posebnih bonusa za uspešan rad. ${ }^{81} \mathrm{U}$ svakom slučaju, ostalo se na pomenutoj cifri, tako da su tek tridesete godine donele povećanje izdataka za nagrade, koja je iznosila 60 dinara po obučenom vojniku. Upoređujući realnu vrednost dinara i kupovnu moć, primetno je da je ovo povećanje imalo učinka. ${ }^{82}$ Stvaranje povoljnih uslova za rad i stimulisanje učitelja uticali su umnogome na ozbiljnost izvođenja nastave.

Angažovanje vojnih vlasti na sprovođenju analfabetskih kurseva kod nepismenih regruta teklo je naporedo sa opismenjavanjem u civilstvu. Broj kurseva održanih dvadesetih godina prošlog veka u vojsci nije zaostajao za brojem u građanstvu, dok su tridesete godine donele zakonske regulative u ovoj oblasti i daleko ozbiljniji rad. Iako je za kurseve izdvajano manje sredstava nego u godinama pre ekonomske krize, njihov broj i značaj u vojsci nije zaostajao za onima u građanstvu. Angažovanjem lokalnih učitelja obezbedio se planski rad predviđen programom

${ }^{76}$ AJ, 66-2234, Ministarstvo vojske i mornarice Ministarstvu prosvete f. đ. br. 12337, 7. april 1921.

${ }^{77}$ Isto, Izveštaj Ministarstva prosvete o. p. br. 21917, 18. maj 1921.

${ }^{78}$ Isto, Ministarstvo vojske i mornarice Ministarstvu prosvete m. p. đ. br. 14214, 20. mart 1939.

${ }^{79}$ AJ, 66-562, Naredbe Ministarstva prosvete za otvaranje analfabetskih kurseva.

${ }^{80} \mathrm{Na}$ traženje Ministarstva vojske i mornarice da se odobri suma u iznosu od 586.500 dinara za nabavku nastavnih sredstava, ministar prosvete je odgovorio da, usled velikog broja kurseva kao i većih nagrada učiteljima u građanstvu (50 dinara), nije u mogućnosti da odobri traženi iznos. AJ, 66-2234, Pismo ministra prosvete ministru vojnom o. n. br. 8575 od 22. februara 1923.

${ }^{81}$ Isto, Dopisi Ministarstva vojske i mornarice Ministarstvu prosvete pov. f. đ. br. 1954 od 19. februara 1923. i đ. br. 36936 od 15. oktobra 1924.

${ }^{82}$ Godine 1923. 40 dinara iznosilo je 2,5 švajcarska franka, dok je 1933. godine 60 dinara iznosilo 4,2 franka. Usled rasta vrednosti dinara 1937. godine porasla je i vrednost nagrade na 6 franaka. И. Бецић, н. д., 210. 
propisanim od strane Ministarstva prosvete. Povećanje nagrade po obučenom vojniku dovelo je do stimulisanja i stalnog angažovanja učitelja u garnizonima.

Rezultat ovih napora bio je dvostruko veći broj kurseva u vojsci, čime je ova organizacija postajala značajan faktor u opismenjavanju i podizanju kulturnog nivoa stanovništva.

\section{REFERENCE}

- Bajagić, Dušan. „Stjepan Radić kao ministar prosvete Kraljevine SHS“. Tokovi istorije, br. 4, (2006), 139-159.

- Becić, Ivan. „Rad na opismenjavanju regruta kraljeve garde“. Vojno-istorijski glasnik, br. 2, (2014), 202-218.

- Bjelajac, Mile. „Vojska kao faktor modernizacije“. U: Srbija u modernizacijskim procesima XX veka. Ur. Latinka Perović, i dr., 355-359. Beograd: Institut za noviju istoriju Srbije, 1994.

- Bjelajac, Mile. Vojska Kraljevine SHS/Jugoslavije 1924-1935. Beograd: Institut za noviju istoriju Srbije, 1994.

- Čalić, Mari Žanin. Socijalna istorija Srbije 1815-1941. Beograd: Clio, 2004.

- Definitivni rezultati popisa stanovništva od 31. marta 1931, knjiga III, prisutno stanovništvo po pismenosti i starosti. Beograd: Opšta državna statistika, 1938.

- Dimić, Ljubodrag. Kulturna politika Kraljevine Jugoslavije, I-III. Beograd: Stubovi kulture, 1996-1997.

- Isić, Momčilo. „Neuspeh osnovnoškolskog sistema u Srbiji za vreme Kraljevine Jugoslavije“. Tokovi istorije, br. 4, (2006), 31-55.

- Isić, Momčilo. Osnovno školstvo u Srbiji 1918-1941. Beograd: Institut za noviju istoriju Srbije, 2005.

- Isić, Momčilo. „Pismenost u Srbiji u prvoj polovini XX veka“, Tokovi istorije, br. 1-2, (1993), 91-103.

- Jovanović, Vladan. Vardarska banovina 1929-1941. Beograd: Institut za noviju istoriju Srbije, 2011.

- Jovanović, Vladan. „Istorijsko, svakodnevno i privatno na prostoru Vardarske banovine“. U: Privatni život kod Srba u XX veku. Urednik Milan Ristović, 543-579. Beograd: Clio, 2007.

- Milosavljević, Svetislav. O moralnosti, naučnom i fizičkom vaspitanju oficira po komandama. Beograd: b. i., 1926.

- Panić, Ilija. „Vojska i opšte obrazovanje naše školske omladine“. Ratnik, XIXII, (1927), 87-95.

- Službeni vojni list 1930. Beograd: Ministarstvo vojske i mornarice, 1931.

- Stanišić, Bajo. „Moralno vaspitanje vojnika“. Ratnik, VII-VIII, (1937), 105-113.

- Velojić, Dalibor. „Uloga vojske u modernizaciji grada града (niški garnizon)“. Vojno-istorijski glasnik, br. 1, (2012), 71-88.

- Vojno-sanitetski statistički godišnjak Kraljevine SHS 1926. i 1927, knjiga II. Beograd: Ministarstvo vojske i mornarice, 1928. 
DALIBOR VELOJIĆ, PhD, Research Associate

Institute for Serbian Culture

Priština - Leposavić, Republic of Serbia

d.velojic@yahoo.com

\section{ANALPHABETIC COURSES \\ IN THE ROYAL YUGOSLAV ARMY 1918-1941}

\section{Summary}

After the end of the First World War, the newly formed state of Serbs, Croats and Slovenes/ Kingdom of Yugoslavia was burdened with a Distinctive set of challenges reflecting its political and economic development rate, as well as cultural heritage. Different laws and systems of elementary education pointed at inequality and the need to create a unique organization. Statistical data show that northern and western parts of the country were at a much higher level of cultural and educational development, whereas in the south and other underdeveloped areas illiteracy rate was even up to $90 \%$. The significant number of illiterate people was among the female population, reflecting the fact that patriarchal society did not recognize emancipation of women. Therefore, the aim of the state was to improve the educational status of young people by opening as many elementary schools as possible, particularly in underdeveloped and distant areas, as well as training the teachers. One of the taken measures was organizing analphabetic courses, with the aim of teaching the population deprived of schooling to read and write within a short period of time. The military also participated in these activities, given that all healthy and capable male population had to pass through it.

Military authorities and units treated the problem of illiteracy very seriously, showing the same amount of effort as civil organizations in addressing the illiteracy. Serious approach and clear strategy were particularly prominent in 1930 s, when this activity gained a legal support. Ultimately, a number of analphabetic courses in the armed forces was twice as high then in the civilian population, and the number of its trained analphabets was higher as well. The research indicates that the military had an important role in raising the educational level of its recruits, particularly those from southern areas of the country.

KEYWORDS: literacy, Royal Yugoslav Army, teaching recruits to read and write, analphabetic courses 